\title{
Dua Kutub dalam Satu Kebangkitan: Perbandingan Refleksi Kebangkitan Menurut Thomas F. Torrance dan Karl Rahner
}

\author{
Alfonsus Ardi Jatmiko a,1 \\ Program Magister Teologi Fakultas Teologi Universitas Sanata Dharma a \\ ardidejesuit@gmail.com ${ }^{1}$
}

\section{Keywords:}

metode teologi, kebangkitan, teologi alamiah, teologi transendental, kodrat objek, harapan transendental, pluralitas teologi Kristiani.

\section{ABSTRACT}

The doctrine of the Resurrection in the Christian faith is still a relevant topic in theological debate for Christians themselves, non-Christians, or even atheists. The questions in this debate show that people desire to learn more about the topic. The presence of theologians who reflect on the Resurrection as a response to the development of the times can help people of all faiths to deepen their knowledge of the Resurrection. Two theologians who focused on the Resurrection were Thomas F. Torrance and Karl Rahner. They have different methodological approaches, and thus produce different theological conclusions. Torrance uses natural theology to examine the Resurrection. He emphasizes the nature of the object as a determinant of the subject's rational structure. In contrast to Torrance, Rahner offers a reflection of the resurrection that emphasizes the subject. The use of transcendental theology in examining the Resurrection results in the constitutive condition of humans as historical and transcendent beings. The differences of their Resurrection theological approaches show that Christian theology is plural. Each preserves and inherits a unique tradition of Protestant and Catholic theology and is influenced by their theological methods. Theology is not limited to the teachings of the Church, yet Church doctrines becomes a starting point and foundation for developing dynamic theological reflections to respond to contemporary developments.

\section{TAK KUNJUNG USAI DIPERTANYAKAN}

Manusia dengan pengetahuannya tidak akan pernah berhenti bertanya tentang segala hal. Apalagi yang menyangkut tentang hidupnya, baik secara langsung maupun tidak langsung. Realitas yang sudah terbentang di depannya belum tentu menjadi jaminan baginya untuk meyakini bahwa itu merupakan sebuah kebenaran. Manusia akan terpantik untuk bertanya agar ia semakin mendapatkan kejelasan tentang apa yang membuatnya ragu. Pertanyaan tersebut menjadi suatu jembatan baginya untuk 
masuk dalam pergulatan intelektualnya bahkan dalam pergulatan imannya.

Mempertanyakan tentang kehidupan setelah kematian menjadi suatu bagian dalam hidup manusia. Bagi manusia, persoalan tentang hal itu merupakan persoalan yang belum jelas secara pasti, bahkan soal kebangkitan dalam iman Kristiani. Penjelasan-penjelasan yang ada di dalam ajaran setiap agama tentang kehidupan setelah kematian hanya dapat diyakini dalam kebenaran iman. Soal pembuktian empiris dari apa yang dijelaskan di dalam ajaran setiap agama tersebut masih dapat diperdebatkan kebenarannya. Oleh karenanya dalam arti tertentu, kehidupan setelah kematian memang masih dalam suatu misteri yang nantinya misteri itu akan terkuak ketika kita yang mengalami sendiri setelah kematian.

Ada beberapa orang muda bertanya kepada penulis tentang kebangkitan dalam iman Kristiani. Bahkan salah satu yang menanyakannya adalah orang muda Muslim. Ia menanyakan hal tersebut kepada penulis, agar ia juga mengerti kehidupan setelah kematian dari sudut pandangan iman Kristiani. Persoalan tentang kehidupan setelah kematian, khususnya kebangkitan, tidak lagi menjadi pertanyaan-pertanyaan yang dilontarkan oleh orang tua yang sedang menghayati masa tuanya. Orang muda yang masih menjalani hidup lama di dunia pun juga telah memikirkan apa yang akan terjadi setelah kematian. Dalam hal ini penulis hanya menekankan bahwa pertanyaanpertanyaan yang bernada eskatologis ini bukanlah sesuatu yang ada di atas langit; tidak pernah dijangkau oleh banyak orang. Pertanyaan-pertanyaan ini tidak hanya relevan bagi mereka yang sedang menghadapi sakratul maut saja, melainkan juga relevan bagi banyak orang yang masih menjalani peziarahan hidupnya di dunia, bahkan orang muda sekalipun. Mereka meyakini bahwa hidupnya setelah kematian juga ditentukan oleh apa yang mereka lakukan selama hidup di dunia. Dengan mengetahui lebih mendalam tentang kehidupan setelah kematian, mereka akan terpacu untuk mempersiapkan dirinya sebaik mungkin selama hidupnya di dunia.

Ajaran Gereja menyebutkan bahwa kehidupan kekal itu diawali dengan kebangkitan badan pada saat hari kedatangan Yesus yang kedua kalinya, yaitu pada saat hari penghakiman terakhir. Hari itu adalah hari ketika Yesus, Sang Raja Abadi, menjadi hakim atas segala bangsa. Semua makhluk hidup yang mati akan dibangkitkan oleh Allah. Kemudian Yesus akan memisahkan orang-orang yang akan masuk ke surga dan ke neraka, seperti Ia memisahkan domba dan kambing. ${ }^{1}$ Mereka para "domba” akan hidup kekal bersama Allah dan para "kambing" akan hidup selamanya di neraka.

Janji Yesus bukanlah suatu utopia belaka melainkan pasti akan terjadi, yaitu ketika Ia akan datang untuk kedua kalinya. Yesus sendirilah yang menjadi model dan acuan kebangkitan badan dalam ajaran Gereja. Ia pun menyebut diri-Nya "Akulah kebangkitan dan hidup" sebagai penegasan bahwa dengan beriman kepada-Nya, penulis juga akan mengalami kebangkitan seperti yang akan dialami oleh Yesus. Meskipun tidak terlalu mendalam, sekurang-kurangnya pengetahuan iman yang sederhana itu membawa penulis pada iman akan kehidupan kekal setelah kematian.

Pertanyaan lebih lanjut adalah soal kebangkitan badan itu sendiri. Pada saat

Mat 25: 31-46 
Yesus datang kedua kalinya, ${ }^{2}$ Ia akan membangkitkan orang-orang mati. ${ }^{3}$ Akan tetapi semua itu tidak ada yang tahu kapan kebangkitan badan pasti akan terjadi. Bahkan Yesus pun juga tidak tahu secara pasti kapan hal itu akan terjadi. ${ }^{4}$ Soal kebangkitan orang mati sendiri, Injil banyak mengisahkannya sebagai mukjizat kebangkitan orang mati yang dilakukan oleh Yesus. Dalam Injil Yohanes misalnya, Lazarus dibangkitkan oleh Yesus. ${ }^{5}$ Akan tetapi bukan kebangkitan seperti itu yang penulis maksudkan, karena ia pun akan mengalami kematiannya kembali. Yang penulis maksudkan adalah kebangkitan yang membawa pada kehidupan kekal. Ajaran Gereja sudah menjelaskan soal kebangkitan badan dengan cukup baik. Meskipun demikian, kebangkitan badan dalam arti tertentu juga masih menjadi misteri.

Dalam tulisan ini, penulis menawarkan suatu perbandingan refleksi teologis kebangkitan dari dua teologyang berbeda latar belakang. Thomas F. Torrance merupakan seorang teolog Protestan dan Karl Rahner adalah seorang teolog Katolik. Tawaran perbandingan ini merupakan suatu cara untuk memperdalam pergulatan intelektual dan iman khususnya terkait dengan persoalan kebangkitan pada zaman modern. Dengan adanya refleksi teologis dari Torrance dan Rahner ini, refleksi teologis kebangkitan pun kemudian tidak hanya berhenti pada ajaran Gereja. Justru ajaran Gereja menjadi suatu titik tolak untuk memperdalam refleksi teologis kebangkitan sebagai bagian untuk menanggapi berkembangnya pemikiranpemikiran modern yang berpengaruh pada ajaran ini.

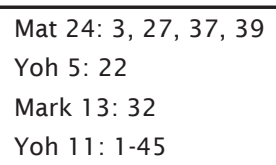

\section{REFLEKSI TEOLOGIS KEBANGKITAN DALAM TERANG TEOLOGI ALAMIAH MENURUT THOMAS F. TORRANCE}

\section{Perekonstruksi Teologi Alamiah}

Dalam teologi Protestan, nama Thomas F. Torrance cukup dikenal luas. Selain mengajar teologi di beberapa negara dan menduduki jabatan penting di Universitas Edinburgh, Skotlandia pada tahun 1950, ia juga dikenal karena tulisan-tulisan teologi yang cukup mendalam, terutama refleksi teologisnya dengan paham Trinitas dan karya-karya lainnya dalam usahanya mendialogkan antara teologi dan ilmu alam. Refleksi kebangkitan juga tidak luput dari perhatian Torrance. Penulis akan menyampaikan secara singkat teologi alamiah yang digunakan Torrance sebagai pisau analisis sehingga refleksi kebangkitan akan lebih mudah untuk dipahami.

Dalam mengembangkan pemikiran teologisnya, Torrance dipengaruhi oleh para dosennya yaitu Hugh Ross Mackintosh, Daniel Lamont, dan Karl Barth. ${ }^{6}$ Ketiga dosennya itu, mempengaruhi refleksi teologis Torrance dalam beberapa bidang yang berbeda: Mackintosh mempengaruhinya dalam bidang teologi dogmatis, Lamont menginspirasinya dalam hal dialog dengan ilmu alam, khususnya penggunaan metode ilmu alam dalam teologi, dan Barth banyak mempengaruhinya dalam bidang teologi dogmatis dan metode teologi, khususnya teologi alamiah. ${ }^{7}$

Dalam "Natural Theology in the Thought of Karl Barth", ${ }^{8}$ Torrance menekankan

\footnotetext{
Paul D. Molnar, Thomas F. Torrance: Theologian of The Trinity (Surrey: Ashgate, 2009), 3-5.

7 Bdk. Molnar, Thomas F. Torrance, 4, bdk. Alister McGrath, An Intellectual Biography (Edinburgh: T\&T Clark, 1999), 31.

8 Thomas F. Torrance, "Natural Theology in the Thought of Karl Barth", Transformation \& Convergence in the Frame of Knowledge: Explorations in the Interrelation of Scientific and Theological Enterprise (Grand Rapids: Eerdmans, 1984), 285301.
} 
bahwa Barth berfokus pada peranan rahmat Allah untuk mencapai pengetahuan akan Allah. Melalui peranan rahmat Allah itu, Barth tidak serta merta mengabaikan struktur rasional subjek penerima rahmat. ${ }^{9}$ Menurut Torrance, justru Barth melibatkan struktur rasional subjek saat menerima rahmat Allah. Meskipun demikian, Barth mengkritik teologi alamiah jika hanya berlandaskan otonomi manusia melalui struktur rasional subjek. Jika teologi alamiah ini menjadi otonom karena struktur rasional subjek, maka akan berlawanan dengan peranan rahmat Allah untuk sampai pada pengetahuan akan Allah.

Bertitik tolak pada pemahaman Barth akan teologi alamiah, Torrance pun menanggapi metode teologi alamiah yang berkembang zaman itu. Pertama-tama, Torrance membangun dasar filosofiyang kuat sebagai landasannya. Penulis mengambil salah satu pokok dalam filsafat Torrance, yaitu tentang realitas, objektivitas, dan logika. Realitas bagi Torrance merupakan ikatan gagasan yang saling terkait, antara keberadaan realitas sesungguhnya di luar pengamat, status ontologis dari kebenaran, dan hubungan erat antara realitas pada dirinya sendiri dan realitas seperti yang terlihat oleh pengamat. $^{10}$ Objektivitas dipahami Torrance sebagai sebuah realitas yang disusun dari sintesis antara elemen pengetahuan empiris dan teoretis. ${ }^{11}$ Di sini ada ikatan yang kuat antara cara realitas dalam pemahaman intrinsik mereka sendiri dan cara mereka menampakkan diri sebagai fenomena yang ditentukan oleh tatanan internal dan struktur realitas. Sedangkan logika, menurut Torrance, menjadi cara untuk mensintesiskan antara realitas dan objektivitas. ${ }^{12}$ Ia membuat sintesis antara logika bentuk empiris dan logika bentuk sistematik dalam rasionalitas subjek untuk sampai pada pengetahuan yang diterima oleh manusia. Ini adalah tahap terakhir dalam proses mengetahui realitas di luar pengamat. Dengan adanya landasan filosofis ini, ia sangat menekankan suatu kodrat dari realitas sebagai objek yang dapat menentukan objektivitasnya di dalam struktur rasional subjek. Tidak ada ruang bagi subjek untuk mengobjektivasi realitas sebagaimana adanya. Ini menjadi semakin jelas arah teologi alamiah yang ingin dituju oleh Torrance. Ia menggunakan kerangka dasar filsafatnya itu untuk merekonstruksi teologi alamiah tradisional. Teologi alamiahnya menekankan pewahyuan diri Allah dalam diri Yesus, sebagai objek, untuk menentukan pengetahuan manusia akan Allah dan bukan pada pengetahuan kodrati manusia yang ditekankan oleh teologi alamiah tradisional.

Torrance mengkritik teologi alamiah tradisional dengan tiga argumen dasar, yaitu pertama ${ }^{13}$, untuk sampai pada pengetahuan akan Allah hanya perlu melalui pribadi Yesus sebagai pewahyuan Allah. Pewahyuan tidak hanya secara umum dalam ciptaan, melainkan lebih daripada itu secara khusus dalam pribadi Yesus. Otonomi pengetahuan manusia dalam teologi alamiah ditolaknya karena menitikberatkan pada otonomi struktur rasional manusia yang bisa membuat distorsi terhadap pengetahuan akan Allah.

\footnotetext{
Bdk. Torrance, "Natural Theology", 294.

10 Alexander John Dolman Irving, "T.F. Torrance's Natural Theology Understood in Its Intellectual Context: The Synthesis of Rational Structure and Material Content" (Oxford: The University of Oxford, 2017), 64.

1 Irving, "T.F. Torrance's Natural Theology", 124.
}

\footnotetext{
12 Bdk. Irving, "T.F. Torrance's Natural Theology", 158.

13 T. F. Torrance, The Doctrine of Jesus Christ: Auburn Lectures, 1938-1939 (Eugene: Wipf and Stock, 2002), 21, 26-28, 61, 6870, 96, 118.
} 
Kedua ${ }^{14}$, melalui rahmat Allah, manusia dapat terbantu untuk sampai pada pengetahuan akan Allah. Akan tetapi rahmat Allah itu dapat rusak karena dosa. Dosa inilah yang dapat merusak pengetahuan akan Allah melalui otonomi struktur rasional manusia, sehingga manusia merasa yakin bahwa pengetahuan akan Allah hanya didapatkannya melalui struktur rasional manusia. Dengan kata lain, otonomi teologi alamiah tradisional dapat mendistorsi pengetahuan akan Allah karena dosa manusia.

$K_{\text {etiga }}{ }^{15}$, teologi alamiah yang otonom diidentifikasikan dengan otonomi struktur rasional yang menekankan subjek sebagai penentu pengetahuan akan Allah. Di sinilah keterbatasan yang akan dialami oleh manusia saat berusaha untuk sampai pada pengetahuan akan Allah. Inilah yang dimaksudkan oleh Torrance dengan adanya distorsi dalam pemahaman manusia atas pengetahuan akan Allah.

Dengan adanya kritik tersebut, Torrance lantas merekonstruksi teologi alamiah yaitu dengan menekankan instra-struktur rasional objek. ${ }^{16}$ Ia menekankan bahwa objeklah yang menjadi dasar pengetahuan daripada struktur rasional subjek. Objek tersebut adalah pewahyuan diri Allah dalam diri Yesus. Torrance dalam hal ini lebih menekankan sisi aposteori daripada apriori dalam pengetahuan akan Allah. Dengan mengetahui dasar-dasar refleksi teologi Torrance melalui tokoh yang berpengaruh dan teologi alamiahnya, kita akan semakin terbantu untuk memahami refleksi teologis Torrance tentang kebangkitan.

Thomas F. Torrance, Calvin's Doctrine of Man (London: Lutterworth Press, 1949), 65-68. Torrance, "The Word of God and the Nature of Man", Theology in Reconstruction (Michigan: William B. Eerdmans Publishing Company, 1965), 105.

15 Irving, "T.F. Torrance's Natural Theology", 251-254.

16 Thomas F. Torrance, Reality and Scientific Theology (Edinburgh: Scottish Academic Press, 1985), 40.

\section{Kodrat Peristiwa Kebangkitan sebagai Penentu Struktur Rasional Subjek}

Torrance, dalam Space, Time, and Resurrection, membagi refleksinya tentang kebangkitan menjadi beberapa bagian, yaitu 1) bertitik tolak dari Kitab Suci, 2) relasi kebangkitan dengan pribadi Yesus, 3) relasi kebangkitan dengan penebusan, dan 4) sifat dasar kebangkitan. Pertama, Kitab Suci sebagai titik tolak. Kebangkitan yang bertitik tolak pada Kitab Suci ini menekankan bahwa benih-benih pemaknaan kebangkitan sudah ditemukan di Perjanjian Lama, meskipun tidak ada pandangan tentang kebangkitan di dunia Israel dalam konteks Perjanjian Lama. ${ }^{17}$ Torrance pun juga menyebutkan bahwa kebangkitan memiliki makna kuat dalam relasinya dengan perjanjian antara Allah dan umat Israel, pemulihan kehidupan umat Israel di mata Allah, pengangkatan penyelamat dari kalangan mereka, dan gagasan penebus yang dijanjikan oleh Allah. ${ }^{18}$ Refleksi kebangkitan menurut Perjanjian Lama ditegaskan lagi menurut Perjanjian Baru, yang secara khusus berfokus pada peristiwa kebangkitan Yesus. Ia menyebutkan bahwa kebangkitan dalam Perjanjian Baru dapat dimaknai sebagai pengangkatan Yesus sebagai Mesias, Nabi, Imam, dan Raja yang diurapi. ${ }^{19}$ Pengangkatan tersebut hanya terjadi karena adanya peran serta Allah dalam membangkitkan Yesus. Kebangkitan yang dialami oleh Yesus ini tidak hanya berdampak pada kondisi eksistensi Yesus saja, melainkan juga berdampak pada seluruh kondisi eksistensi manusia. Manusia dikembalikan pada kondisi kudus asalinya di hadapan Allah. Torrance pun juga menilai bahwa kebangkitan Yesus tidak seperti kebangkitan yang dialami oleh

\footnotetext{
17 Thomas F. Torrance, Space, Time, and Resurrection (Michigan: William B. Eerdmans Publishing Company, 1976), 28-30.

18 Torrance, Space, Time, and Resurrection, 28-30.

19 Torrance, Space, Time, and Resurrection, 33-35.
} 
Lazarus. Setelah bangkit, Yesus tidak akan mati lagi seperti yang dialami oleh Lazarus dan badan-Nya mengalami perubahan yang radikal.

Kedua, relasi kebangkitan dan pribadi Yesus. Pada bagian ini, status yang ada dalam diri Yesus, yaitu dua kodrat dalam satu pribadi menjadi titik tolaknya. ${ }^{20}$ Dengan status itu, Ia hadir di dunia untuk menjalankan misi penebusan yang dikehendaki oleh Allah atas penghapusan dosa manusia. Dengan motif penebusan itu, ia menjalankan dengan penuh ketaatan yang memiliki aspek pasif dan aktif. Melalui ketaatan pasif, Yesus menjalankan penebusan dengan total sampai mati atas inisiatif Allah. ${ }^{21}$ Kebangkitan Yesus pun kemudian dimaknai sebagai campur tangan Allah untuk membangkitkan Yesus dan merupakan afirmasi atas misi penebusan yang sudah dijalankan Yesus di dunia. Ketaatan aktif dari ketaatan Yesus berlandaskan kasih yang begitu kuat antara Allah dan Putra. ${ }^{22}$ Kesatuan kasih yang begitu kuat dengan Allah itulah yang menyebabkan Ia mampu mengatasi kuasa maut yang membelengguNya saat mengalami kematian.

Torrance juga menegaskan bahwa, kelahiran dan kebangkitan Yesus tidak dapat saling terpisahkan dan harus dipahami dalam terang masing-masing. ${ }^{23}$ Melalui hadirnya Yesus di dunia, perlawanan terhadap kuasa jahat pun dilakukan oleh Yesus melalui sengsara, wafat, dan kebangkitan-Nya agar manusia dipulihkan ke dalam kondisi asalinya yang kudus. Relasi antara kelahiran dan kebangkitan pun kemudian dipahami sebagai bentuk adanya sebuah penciptaan

\footnotetext{
Torrance, Space, Time, and Resurrection, 46. Torrance, Space, Time, and Resurrection, 50-51.

Torrance, Space, Time, and Resurrection, 53-54.

Torrance, Space, Time, and Resurrection, 56.
}

baru yang disebabkan oleh kebangkitan Yesus. $^{24}$

Ketiga, relasi kebangkitan dan penebusan. Pada bagian ini Torrance membawa pada pemahaman atas pembenaran, rekonsiliasi, dan penebusan. Torrance menilai bahwa ada relasi yang cukup kuat antara pengampunan dan pembenaran dalam konteks kebangkitan. Dalam kebangkitan, Allah menolak dosa dan status manusia sebagai makhluk berdosa, sekaligus Allah juga berkenan untuk mengampuni dan membenarkan bahwa status manusia dikembalikan menjadi anak Allah. ${ }^{25}$ Ketika Yesus bersabda pada orang lumpuh bahwa dosanya diampuni, artinya sabda Yesus itu merupakan sabda penyembuhan. Pengampunan dan penyembuhan pun kemudian benar-benar terjadi sebagai sebuah realita sepenuhnya dalam peristiwa fisik penyembuhan itu sendiri. Dengan demikian dapat dikatakan bahwa kebangkitan dalam arti ini merupakan peristiwa ketika Allah menyatakan seorang manusia benar, karena memang manusia itu benar. ${ }^{26}$

Torrance menegaskan bahwa rekonsiliasi antara manusia dan Allah tercapai dan menjadi sempurna dalam kebangkitan. ${ }^{27}$ Kebangkitan mengembalikan relasi antara Allah dan manusia ke kondisi asalinya. Karena kebangkitan, tidak ada lagi pertentangan antara Allah dan manusia yang diakibatkan karena dosa manusia. Selain itu, melalui pernyataan yang dikatakan oleh Yesus bahwa ia adalah "kebangkitan dan hidup" semakin mempertegas bahwa penebusan menjadi hal kekal dan abadi dan rekonsiliasi pun menjadi realitas benar-benar ada dan terjadi, bahkan senantiasa ada sepanjang sejarah antara manusia dan Allah.

\footnotetext{
Bdk. Torrance, Space, Time, and Resurrection, 58.

Torrance, Space, Time, and Resurrection, 62

Torrance, Space, Time, and Resurrection, 63.

Torrance, Space, Time, and Resurrection, 66.
} 
Dalam relasinya dengan penebusan, kebangkitan dapat dipandang sebagai penebusan bagi keseluruhan manusia. Dalam konteks ini, penebusan kemudian diartikan sebagai pembebasan manusia dari kuasa jahat dosa dan kebinasaan yang disebabkan oleh kematian. Dengan kata lain, kebangkitan pun dapat diartikan sebagai penebusan, yaitu pemulihan kembali manusia dalam kepenuhan kemanusiaannya. ${ }^{28}$ Dalam kondisi ini, manusia kembali dipersatukan dengan Allah.

Kebangkitan Yesus merupakan sebuah peristiwa historis dalam keseluruhan hidup Yesus. Di sanalah kebangkitan memiliki arti penting dalam sejarah manusia di hadapan Allah yaitu adanya pemulihan kembali dan penciptaan kembali eksistensi manusia yang rusak akibat dosa ke dalam hidup baru, sebagai anak Allah. ${ }^{29}$ Jika kebangkitan Yesus tidak menjadi peristiwa historis, maka penebusan menjadi sia-sia belaka karena hal ini tidak terjadi dalam sejarah umat manusia. Sia-sia pulalah wafat dan kebangkitan Yesus.

Keempat, peristiwa kodrati kebangkitan. Torrance menjelaskan bahwa kebangkitan Yesus merupakan sebuah peristiwa historis dalam keseluruhan hidup Yesus. Peristiwa tersebut berada pada waktu tertentu di masa lalu dan di tempat tertentu pula. Oleh karena itu, peristiwa kebangkitan Yesus dijadikan sebagai peneguhan iman para murid atas apa yang diyakininya dari ajaran Yesus. Sebagai peristiwa historis, kebangkitan memiliki arti penting dalam sejarah manusia di hadapan Allah, yaitu adanya pemulihan kembali dan penciptaan kembali eksistensi manusia yang rusak akibat dosa ke dalam hidup baru, sebagai

\footnotetext{
28 Torrance, Space, Time, and Resurrection, 74.

29 Torrance, Space, Time, and Resurrection, 87.
}

anak Allah. Jika kebangkitan Yesus tidak menjadi peristiwa historis, maka penebusan menjadi sia-sia belaka karena hal ini tidak terjadi dalam sejarah umat manusia. Sia-sia pulalah wafat dan kebangkitan Yesus.

Jika kebangkitan Yesus merupakan sebuah peristiwa yang terjadi di dalam sejarah keseluruhan hidup Yesus, apakah kebangkitan manusia juga ada di waktu historis? Kebangkitan manusia disebut sebagai peristiwa historis, jika hanya merujuk pada kompleksitas peristiwa historis dan ada saksi atas peristiwa tersebut. ${ }^{30}$ Akan tetapi, kebangkitan lebih dari sekadar peristiwa historis dengan menekankan adanya saksi atas peristiwa tersebut. Kebangkitan merupakan sebuah penebusan dari ikatan dosa yang membinasakan manusia. Maka kebangkitan itu sendiri sebenarnya menembus struktur dan batas ruang dan waktu historis. Demikianlah juga apa yang terjadi dengan penebusan Yesus. PenebusanNya juga berdampak pada pelepasan manusia dari kejahatan dan kehancuran atas dosa di dunia yang ada dalam ruang dan waktu.

Dunia sebagai tempat kita hidup ini ada di dalam waktu yang tidak abadi. Waktu ini pula tidak akan mengalami kemunduran, melainkan senantiasa maju ke depan. Demikian pula dengan peristiwa yang terjadi di dunia ini. Kebangkitan, di tengah realitas dunia semacam ini, merupakan peristiwa yang akan melawan kehancuran dan kebusukan dunia, maka kebangkitan adalah hal baru dalam peristiwa historis; sebuah peristiwa yang ada di dalam peristiwa temporal dan tidak berjalan mundur ke

\footnotetext{
30 Berdasarkan Salvation in History karya Oscar Cullman, Torrance menjelaskan bahwa memang kebangkitan Yesus tidak dapat diakses oleh kontrol historis (historical control) dan tidak dijelaskan di Injil secara mendetail. Akan tetapi peristiwa kebangkitan memiliki fakta yang setidaknya secara teoritis dapat dibuktikan dalam kerangka historis, yaitu penampakan Yesus setelah kebangkitan kepada para muridNya dan makam kosong. (Torrance, Space, 86.)
} 
masa lalu, melainkan maju ke masa depan. Ini pulalah yang terjadi di dalam peristiwa kebangkitan Yesus. Ia tidak mati melainkan hidup, pun juga Ia tidak binasa dalam kematian. Ia hidup di masa sekarang sebagai kehidupan nyata yang terus berkelanjutan. Ia akan bertemu manusia di sini dan sekarang, serta menunggu manusia memasuki masa depan.

\section{REFLEKSI TEOLOGIS KEBANGKITAN DALAM TERANG TEOLOGI TRANSENDENTAL MENURUT KARL RAHNER}

\section{Teologi Transendental: Teologi yang berciri Antropologi}

Karl Rahner bukanlah teolog kelas teri. Banyak orang mengenalnya karena pemikiran teologisnya yang tajam dan karena keterlibatannya dalam Konsili Vatikan II. Awalnya ia tidak pernah berandai-andai bahwa akan menjadi seorang teolog. Minatnya terhadap filsafat membuat teman-temannya mengira bahwa ia nantinya akan menjadi dosen filsafat. Akan tetapi keberuntungan tidak berpihak kepadanya. Disertasi filsafatnya ditolak oleh pembimbingnya sendiri. ${ }^{31}$ Sejak saat itulah ia mulai beralih untuk menekuni bidang teologi.

Bukanlah suatu kerugian bahwa Rahner memiliki latar belakang pendidikan filsafat yang cukup kuat. Kedalaman berpikir teologisnya pasti karena adanya horison filsafatnya itu. Dipengaruhi oleh beberapa tokoh besar filsafat dan guruguru filsafatnya, ia menawarkan cara pikir baru dalam berteologi pada zaman modern, yaitu teologi transendental. Sebut saja tokoh besar filsafat itu adalah Thomas Aquinas,

\footnotetext{
31 Philip Kennedy, Twentieth-century Theologians: A New Introduction to Modern Christian Thought (London: I.B. Tauris, 2010), 139.
}

Immanuel Kant, dan Martin Heidegger; sedangkan guru-guru filsafatnya adalah Pierre Rousselot dan Joseph Marechal.

Sebagai seorang Jesuit yang pernah menjalani masa formasi kejesuitan dengan semangat Konsili Vatikan I, corak teologinya tentu saja sangat kuat dipengaruhi oleh aliran neo-skolastik yang berakar pada teologi Thomas Aquinas. ${ }^{32}$ Rahner memiliki pemikiran yang sejalan dengan Aquinas dan ada pulayangberseberangan dengan Aquinas. Misalnya tema tentang sakramen sebagai kesatuan tanda dan kausalitas sebagai tema pemikiran yang sejalan dengan Aquinas. Di lain pihak ada tema yang berseberangan pandangan, misalnya pandangan manusia Aquinas adalah kesatuan jiwa dan badan; sedangkan pandangan manusia Rahner adalah kesatuan historis dan transenden. ${ }^{33}$

Perbedaan pandangan dengan Aquinas tidak hanya itu saja. Rahner dengan filsafat Kantianingin membedah konseppengetahuan metafisis Aquinas. Rahner dipengaruhi filsafat transendental Kant, khususnya tentang kritik rasio murni manusia dalam menanggapi konsep pengetahuan metafisis Aquinas. ${ }^{34}$ Seperti Kant, Rahner ingin mencari prasyarat apa yang memungkinkan manusia dapat mengetahui sesuatu. Dengan dipadukan pemikiran Heidegger, Rahner kemudian membuat pemikiran baru yaitu bahwa manusia tidak terlepas dari kesejarahannya. Dalam kesejarahannya itu manusia bereksistensi dalam wujudnya sebagai ada-menuju-kematian (Sein-zumTode). ${ }^{35}$ Dalam usahanya mensintesiskan

\footnotetext{
$32 \quad$ Bdk. Kennedy, Twentieth-century Theologians, 138.

33 Ethna Regan, "Not Merely the Cognitive Subject: Rahner's Theological Anthropology" dalam Pádraic Conway dan Fáinche Ryan (eds.), Karl Rahner: Theologian for the Twenty-first Century (Oxford: Peter Lang, 2010), 122.

34 Kennedy, Twentieth-century Theologians, 138.

35 Bdk. F. Budi Hardiman, Heidegger dan Mistik Keseharian (Jakarta: Kepustakaan Popular Gramedia, 2003), 90.
} 
tiga tokoh besar itu, Rahner terbantu dengan pemikiran Rouselot dan Marechal. Rouselot membantunya dalam gagasan mengetahui Allah dengan mengunakan akal budi manusia karena sudah mengetahui roh dan "ada" (being). ${ }^{36}$ Sedangkan Marechal mempengaruhi Rahner dalam hal dinamika pikiran manusia harus berakhir pada Ada Absolut. $^{37}$

Lima tokoh filsafat ini memberikan inspirasi dalam perjalanan intelektualitas Rahner. Salah satunya adalah dalam penulisan dua karya besar yang menjadi dasar pemikiran filosofis dan teologisnya. Dua karya besarnya itu adalah Geist in Welt (Spirit in the World) dan Hörer des Wortes (Hearers of the Word). Geist in Welt merupakan disertasi filsafat yang ditolak oleh pembimbingnya sendiri. Buku ini membahas permasalahan pengetahuan metafisis dalam pemikiran Thomas Aquinas yang bertitik tolak pada Summa Theologiae I, q. 84, a. 7. ${ }^{38}$ Sedangkan Hörer des Wortes merupakan uraian implikasi dari pengetahuan metafisis manusia dalam historisitasnya yang terbuka pada pewahyuan Allah. Dari kedua karya besar Rahner ini, corak metode teologi Rahner tergambarkan dengan konkret, yaitu teologi transendental.

Rahner tidak mengikuti para pendahulunya dalam memaknai kata "transendental". Ia menggunakan transendental lebih mengarah pada gabungan antara pengertian transendental Abad Pertengahan dan Modern. ${ }^{39}$ Transendental sebagai sebuah pengalaman yang dimaksudkannya lebih

36 Thomas Sheehan, "Pierre Rousselot and the Dynamism of Human Spirit", dalam Gregorianum 66, no. 2 (1985): 242.

37 Greffrey B. Kelly (ed.), Karl Rahner: Theologian of the Graced Search for Meaning (Minneapolis: Fortress Press, 1992), 4-5.

38 Kennedy, Twentieth-century Theologians, 139.

39 Francis Schüssler Fiorenza, "Method in Theology", dalam Declan Marmion dan Mary E. Hines (eds.), The Cambridge Companion to Karl Rahner (Cambridge: Cambridge University Press, 2005), 77. diartikan sebagai pengalaman akan Allah dan ini sangat berbeda dari Kant yang tidak pernah mengartikan transendental dalam konteks pengalaman. Selain itu, meskipun Rahner mempertahankan pengetahuan apriori, ia tetap mengacu pada pengalaman manusia akan rahmat yang terkondisikan secara historis. Ia lebih menekankan signifikansi antropologis daripada kategori filsafat dalam teologinya.

Titik tolak teologi transendentalnya adalah soal pandangannya terhadap manusia. Ia memandang manusia sebagai kesatuan antropologis antara historis dan transenden. Historis yang dimaksudkannya adalah manusia yang memiliki dimensi historis yang terhubung dengan dunia melalui spasial-temporal dan pengalaman aktualnya. Pengalaman historisitasnya ini termasuk pengalaman akan Allah sendiri. Sadar akan keterbatasan alam historisitasnya, kodrat manusia pun terbentuk untuk dapat melampaui kondisi historisnya. Akan tetapi bukan berarti manusia dapat lepas dari kondisi tersebut. Kondisi semacam ini menjadi kondisi konstitutif manusia, yaitu berada di antara yang terbatas dan yang tidak terbatas yang ditunjukkan dalam transendensi yang tak terbatasnya dan dalam kebebasannya. Pengalaman yang ada di dalam diri manusia tersebut menunjukkan kodrat historis pribadi manusia ketika membuka diri secara radikal kepada yang transenden, sebagaimana diarahkan pada misteri yang mutlak, yaitu Allah.

Keterarahan radikal kepada yang mutlak tidak hanya konstitutif atas kodrat manusia, melainkan hasil dari komunikasi diri historis dan kehadiran secara penuh Allah kepada manusia seluruhnya. Di lain pihak, manusia juga memiliki sebuah apriori dalam dirinya yang memungkinkan 
mereka untuk menjangkau hal yang tak berhingga dan menerima rahmat Allah. Kondisi semacam ini mengarahkan manusia tidak hanya pada pengalaman akan Allah, namun juga pengalaman diri sebagai subyek transendental.

Teologi transendental Rahner ini sangat kuat dalam pembahasan ontologi Thomas Aquinas dengan melibatkan pertanyaan baru yang dipengaruhi oleh Kant dan Heidegger. Rahner menggunakan terminologi filsafat Kantian tanpa menunjukkan ciri filosofisnya dengan membangun sebuah fondasi manusia untuk mengetahui suatu hal, melainkan sebuah ciri teologis, yaitu dalam bentuk kemungkinan tindakan iman. Dalam arti ini Rahner melebihi apriori yang dimaksudkan Kant Apriori Kant untuk memahami ada dan apriori Rahner untuk memahami Allah. ${ }^{40}$ Oleh karena itu, teologi Rahner ini disebutnya sebagai antropologi karena menjelaskan dengan tegas kemungkinan ontologis manusia untuk memahami Allah. ${ }^{41}$

\section{Memahami Kebangkitan dari Kondisi Konstitutif Manusia}

Metode teologi transendental digunakan Rahner dalam merefleksikan ajaran-ajaran Gereja dan bahkan permasalahan teologis yang terjadi pada saat itu. Salah satu dari ajaran Gereja yang direfleksikan Rahner dengan teologi transendentalnya adalah kebangkitan badan. Ia mengawali refleksi tentang kebangkitan badan pada teologi kematian. Kematian dianggapnya sebagai bagian totalitas manusia yang merupakan ada-menuju-kematian (Sein-zum-Tode).

Rahner melampaui refleksi kematian para teolog neo-skolastik yang menyatakan bahwa kematian merupakan keterpisahan

\footnotetext{
$40 \quad$ Regan, "Not Merely the Cognitive Subject", 122.

${ }_{41}$ Regan, "Not Merely the Cognitive Subject", 125.
}

jiwa dan badan. ${ }^{42}$ Soal keterpisahan keduanya, Rahner tidak menolaknya. Ia menambahkan bahwa jiwa yang sudah terlepas itu kemudian tetap memiliki relasi dengan pankosmik. Pankosmik bukanlah berarti bahwa pada saat kematian, seluruh dunia menjadi "badan" bagi jiwa tertentu. ${ }^{43}$ Selain itu pankosmik juga tidak diartikan bahwa jiwa dapat berada di mana pun di dalam alam semesta. Pankosmik yang dimaksudkan oleh Rahner adalah badan yang juga memiliki keterbukaan relasi dengan dunia di sekitarnya. ${ }^{44}$ Maka, jiwa tidak mengalami keterpisahan dengan materialitas pada dirinya sendiri, jiwa sungguh menenggelamkan dirinya dalam relasi yang mendalam dengan materi-materi yang ada di kosmos. ${ }^{45}$

Sebagai aspek personal kematian, Rahner menilai bahwa kematian adalah pilihan moral fundamental. Manusia memilih dalam kebebasannya kematian sebagai eksistensi temporalnya. Pada saat kematian itulah manusia juga mencapai totalitasnya. ${ }^{46}$ Ia tidak pasif menerima kematian, melainkan aktif menyambut kematian itu sebagai pilihan moralnya. ${ }^{47}$ Kematian yang disambut dengan daya aktif manusia itu membawa manusia pada sebuah harapan tentang apa yang akan terjadi setelah kematian.

Rahner menilai bahwa masa depan, seperti kehidupan setelah kematian dipahami sebagai sebuah pokok peristiwa dari masa sekarang. Segala pengetahuan tentang masa

\footnotetext{
42 Gerald O'Collins, Jesus Risen: An Historical, Fundamental, and Systematic Examination of Christ' Resurrection (New York: Paulist Press, 1987), 79.

$43 \quad$ Karl Rahner, On The Theology of Death, diterjemahkan oleh C. H. Henkey (Freiburg: Herder, 1961), 21.

44 Rahner, On The Theology of Death, 22.

45 John O'Donnel, "Karl Rahner on Easter Faith", dalam Gregorianum, vol. 86, no. 2, 2005, 362.

46 Bdk. Karl Rahner, Foundations of Christian Faith, diterjemahkan oleh William V. Dych (London: Darton Longman and Todd, 1978), 270.

47 Rahner, On The Theology of Death, 27.
} 
depan adalah pengetahuan tentang masa sekarang yang berciri eskatologis. Masa depan merupakan pemenuhan keselamatan yang sudah ada dalam komunikasi diri Allah dalam Kristus dan rahmat Roh Kudus. Bagi Rahner, Allah yang adalah Sang Masa Depan Absolut ini dapat dipahami oleh manusia yang merupakan makhluk transenden. ${ }^{48}$ Manusia dengan pengetahuan dan kebebasannya dapat bertransendensi yang tertuju kepada Allah dalam temporalitasnya sebagai cara bereksistensi manusia. Artinya bahwa yang menjadi hal pokok dalam transendensi manusia adalah gerak hidup manusia untuk menuju masa depan dan masa depan itu adalah kematian. Akan tetapi, Rahner justru menegaskan bahwa transendensi manusia akan terus mencari hal yang lebih daripada kematian. Transendensi manusia ini tidak akan dapat dipuaskan dengan masa depan yang tidak terbatas saja, melainkan Allah sebagai Sang Masa Depan Absolut. ${ }^{49}$

Manusia memiliki sebuah harapan transendental atas kebangkitan. Harapan transendental inilah yang menjadi sebuah cakrawala yang menerangi manusia untuk mengalami kebangkitan Yesus di dalam imannya dan bahkan menerima kebenaran dari kebangkitan badan. ${ }^{50}$ Harapan transendental ini akan mencapai ciri khas dari harapan eskatologis yang ditimbulkan oleh harapan yang telah tergenapi. Adanya harapan yang tergenapi itu menjadi sebuah sikap alternatif untuk beriman terhadap apa yang akan terjadi pada kehidupan setelah kematian. Dalam berpengharapan itu, manusia bertindak dalam kebebasannya. Rahner pun menambahkan bahwa harapan transendental ini juga terkait dengan kematian dan keabadian. Ia melihat bahwa

\footnotetext{
O’Donnel, "Karl Rahner on Easter Faith", 362.

Bdk. O’Donnel, “Karl Rahner on Easter Faith”, 362.

Rahner, Foundations of Christian Faith, 269.
}

harapan eksistensi historis manusia berada pada tindakan bebas manusia untuk memilih kematian sebagai usaha untuk menanggapi masa depan. Oleh karenanya, keabadian justru dipandang sebagai waktu yang dihadirkan dari waktu yang menjadi temporalitas sehingga titik akhir hidup manusia dan hal yang pasti di dalam hidup manusia ini dapat dicapai dalam kebebasannya.

Harapan transendental atas kebangkitan juga dipandang di dalam sejarah komunikasi diri Allah melalui rahmat-Nya. Harapan yang ada di dalam manusia ini mengacu pada kemungkinan-kemungkinan yang membawa manusia pada pribadi yang hanya dapat dipahami dalam iman. Pribadi inilah yang disebutnya sebagai "Sang Penyelamat Absolut" dan menurut iman Kristiani, dialah Yesus dari Nazaret.51 Dalam kebangkitan Yesus ini, harapan akan kebangkitan memiliki makna yang sungguh mendalam.

Mengacu pada rumusan teologis tentang kebangkitan Yesus dan kisahkisah kebangkitan Yesus dalam Kitab Suci, kodrat dari pengalaman Paskah tentu saja menjadi sesuatu yang khas. Pengalaman tersebut sungguh berbeda dari pengalamanpengalaman penampakan Yesus atau Maria yang dialami oleh beberapa orang kudus. Pengalaman tersebut juga tidak hasil imajinasi seseorang, bahkan memang terjadi karena ada "hal di luar" diri manusia yang terlibat di dalamnya. Rahner menekankan bahwa penampakan ini berbeda dengan penampakan-penampakan Yesus kepada orang-orang pilihan-Nya setelah kenaikanNya ke surga. Bahkan Gereja pun menolak untuk menyejajarkan mereka. Maka, Rahner menyebutkan bahwa pengalaman tersebut dialami hanya dalam iman dan

Rahner, Foundations of Christian Faith, 280. 
juga mendasari serta membenarkan iman. ${ }^{52}$ Pengalaman ini sungguh unik dan tidak ada suatu pengalaman penampakan religius lainnya yang dapat disejajarkan dengan pengalaman ini. Pengalaman iman para rasul ini berdasarkan dari kesaksian yang mereka alami sendiri atas kejadian penampakanpenampakan Yesus. ${ }^{53}$ Rahner pun juga menambahkan bahwa kebangkitan Yesus hanya dapat dipahami dengan iman karena memang kebangkitan Yesus merupakan objek iman. Tidak ada keterpisahan antara iman dari para rasul dengan objek iman, yaitu kebangkitan Yesus. ${ }^{54}$ Dengan adanya pengalaman semacam ini, para rasul yang menjadi saksi atas kebangkitan Yesus, perlu membagikan atau menceritakan apa yang dialaminya kepada yang lainnya, sehingga kebenaran kebangkitan Yesus terwartakan ke seluruh penjuru.

Ini ingin menegaskan bahwa hanya melalui keyakinan kepada pengalaman para rasul yang dapat membantu orang Kristiani untuk memahami dan mengimani kebangkitan Yesus. Pengalaman para rasullah yang menyatakan bahwa Yesus telah hidup. Sarana-sarana historis lainnya tidak akan dapat membantu orang untuk dapat paham sepenuhnya dan mengimani kebangkitan Yesus. Seandainya fakta-fakta sejarah yang terkait dengan kebangkitan Yesus menunjukkan bahwa hal tersebut sudah sering terjadi dalam sejarah dunia, maka kebangkitan Yesus pun tidak dapat dikatakan sebagai peristiwa bersejarah. ${ }^{55}$ Kebangkitan Yesus lantas tidak memiliki kekhasannya dan menjadi peristiwa umum yang terjadi pada waktu itu. Jika ada orang

\footnotetext{
Rahner, Foundations of Christian Faith, 277.

Rahner, Foundations of Christian Faith, 266.

Karl Rahner, "Experiencing Easter", dalam Theological Investigations, volume 7, diterjemahkan oleh David Boourke (London: Darton, Longman \& Todd, 1971): 159-168.

55 Rahner, Foundations of Christian Faith, 277.
}

yang menyatakan bahwa pengalaman subjektif para rasul tentang Paskah sebagai suatu peristiwa yang benar-benar nyata dan jelas secara historis, ia tidak dapat secara sembarangan menafsirkan pengalaman para rasul ini. Ia harus memahami apa yang para rasul jelaskan dalam peristiwa kebangkitan Yesus. Setelah berusaha memahami kebangkitan Yesus dari pengalaman para rasul, kemudian ia menolak untuk percaya, maka ia pun sebenarnya juga menolak harapan transendental akan kebangkitan dalam dirinya sendiri.

Bagi Rahner, ada keterkaitan antara dimensi transendental dalam diri kita, harapan akan kebangkitan, dan iman dalam kebangkitan Yesus. Keterkaitan ini tidak perlu mengaburkan perbedaan antara kebangkitan Yesus dan harapan kita akan kebangkitan Yesus. Berdasarkan Perjanjian Baru, orang Kristiani memang dapat terbantu untuk membedakan antara kebangkitan Yesus dan kebangkitannya. ${ }^{56}$ Kebangkitan Yesus berdampak pada status diri-Nya, yaitu Yesus dimuliakan sebagai Tuhan dan Mesias. Dalam Perjanjian Baru, kisah-kisah penampakan Yesus dapat memberikan kepastian dan keyakinan bahwa kebangkitan merupakan suatu peristiwa Yesus dimuliakan dan penegasan bahwa Ia duduk ditahtaNya sebagai hakim dan Tuhan atas dunia. Ini menjadi sangat jelas sekali dengan apa yang dimaksudkan dengan harapan kita atas kebangkitan. Manusia juga akan mengalami kondisi badan yang termuliakan.

Dari iman akan kebangkitan Yesus itu, kita dapat melihat bahwa kebangkitan Yesus memiliki konsekuensi kristologis dan soteriologis. Dari pandangan kristologis, kebangkitan Yesus menegaskan kesatuan dua kodrat dalam diri Yesus. Ia

$56 \quad$ Rahner, Foundations of Christian Faith, 278 
mengalami kematian sehingga Ia masuk ke dalam kebangkitan-Nya. Kematian-Nya mendapatkan kebenarannya secara definitif, final, dan tetap dari eksistensi historis Yesus, yaitu kebangkitan-Nya. Rahner juga menegaskan bahwa kebangkitan Yesus ini sebagai peristiwa di mana Allah dan Yesus bertindak dengan penuh kuasa atas kematian Yesus.

Dari pandangan soteriologis, Rahner menekankan adanya relasi antara kesejarahan Yesus di dunia dengan makna kebangkitanNya dalam terang soteriologi. Yesus yang masuk ke dalam sejarah manusia ini akan mengalami apa yang dialami oleh manusia, salah satunya, yaitu kematian. Jika Yesus yang telah mati itu mengalami kebangkitan, demikian pula manusia dan dunia akan dibangkitkan seperti Yesus. Manusia dan dunia mengalami penyempurnaan berkat adanya kebangkitan Yesus. Maka memang perlu juga melihat bahwa kebangkitan-Nya juga berdampak bagi penebusan manusia.

Dampak penebusan yang dilakukan oleh Yesus itu salah satunya adalah kebangkitan badan yang dialami oleh manusia. Rahner menyebutkan bahwa kondisi badan manusia setelah kebangkitan akan berbeda dengan kondisi badan sebelum kematian. Baginya, yang terpenting adalah bahwa manusia tidak mengenakan badan duniawi lamanya lagi, melainkan adanya kebebasan manusia di hadapan Allah dan mengalami penyempurnaan dan pemuliaan. Konsekuensi dari pandangan ini adalah pertanyaan tentang surga. Jika badan mengalami penyempurnaan dan pemuliaan, artinya surga dapat ditanyakan keberadaannya, misalnya tempatnya berada di mana. Menanggapi persoalan ini, Rahner menanggapinya bahwa surga pertama-tama bukanlah soal tempat, melainkan surga dipandang sebagai suatu "tempat" baru yang dipersiapkan oleh Yesus sendiri karena kebangkitan-Nya sendiri. Tubuh Kristus yang telah dimuliakan karena kebangkitan inilah yang menciptakan "tempat" baru itu.

Ketika semua eksistensi manusia di dunia berakhir dalam kematian, dunia tempat tinggal manusia pun juga akan mengalami masa akhirnya. Pada saat itulah dunia juga ikut serta dalam penyempurnaan roh. Roh ini ada dalam relasi dengan Allah, maka dunia diajak untuk ikut serta merubah dirinya menuju keadaan finalitasnya. Argumennya adalah soal keterkaitan dunia dengan roh manusia. The personal spirit yang adalah roh manusia (human spirit) merupakan keseluruhan realitas dunia dan oleh karenanya memang tidak dapat terpisah dari dunia. Masa akhir dunia ini disebutkan oleh Rahner adalah masa ketika sejarah keselamatan mengalami penyempurnaan dan pencapaian akhirnya yang sudah tergenapi dalam Yesus Kristus dan kebangkitan-Nya. Pada saat itulah Yesus datang untuk kedua kalinya dalam kemuliaan dan kuasa-Nya serta pada saat yang bersamaan terjadi kebangkitan umum orang mati.

\section{KEBANGKITAN DARI DUA SUDUT PANDANG: SEBUAH PERBANDINGAN}

Refleksi teologis dua teolog besar yang sudah dijelaskan ini memiliki ciri khas masing-masing. Dari penjelasan tersebut perbedaan mendasar dapat dirumuskan dalam tiga tema yaitu, (1) pendekatkan epistemologis yang berimplikasi pada (2) harapan-iman dan (3) pendekatan ontologis. Pendekatan epistemologis mengawali perbandingan pertama refleksi teologis ini. Pendekatan ini menampilkan suatu perbedaan yang jelas dari cara Torrance 
dan Rahner mengetahui kebenaran epistemologis kebangkitan Yesus. Torrance sangat berpegang teguh bahwa hanya melalui peristiwa kebangkitan Yesus itulah manusia dapat mengetahui kebangkitan Yesus itu sendiri dan Yesus yang telah bangkit. Pandangannya ini berdasarkan prinsip dasar teologi alamiahnya yang menyebutkan bahwa objeklah yang menentukan struktur rasional subjek. Konsekuensinya adalah penolakan terhadap subjektivisme, bahkan subjektivisme dari para rasul yang disebut sebagai kelompok pertama yang melihat langsung penampakan Yesus yang telah bangkit dan makam Yesus yang kosong. Bagi Torrance, ini akan menimbulkan distorsi pengetahuan sehingga pengetahuan yang didapatkan menjadi kabur dan tidak seperti objek yang senyatanya menyingkapkan dirinya sendiri.

Agar tidak mengalami sebuah distorsi dalam memahami kebangkitan Yesus bagi generasi selanjutnya, Torrance pun menegaskanbahwaiman daripara murid yang mengalami secara langsung penampakan dan makam kosong bukanlah satu-satunya bukti yang menandai adanya kebangkitan Yesus dan menjadi dasar dari iman Paskah. Yang paling penting bagi Torrance adalah dengan meyakini adanya kebangkitan Yesus manusia juga telah dibangkitkan oleh Kristus dan telah dimasukkan dalam penciptaan baru. Dengan ini kemudian apa yang menjadi peristiwa objektif dalam peristiwa kebangkitan Yesus memiliki kesesuaian dengan pemahaman subjektif dari manusia yang mengimani kebangkitan Yesus. ${ }^{57}$ Ini jawaban Torrance agar orang-orang zaman ini tetap dapat mengacu pada kebangkitan Yesus yang terjadi ribuan tahun lalu sebagai objek pengetahuan akan kebangkitan

Torrance, Space, 38-39. sehingga mereka tidak mengalami distorsi pengetahuan seperti yang dimaksudkan oleh Torrance. Molnar berkomentar bahwa hal ini seperti sesuatu yang justru membahayakan karena terkesan ada pemikiran subjektif yang seharusnya ditolak oleh Torrance sendiri. ${ }^{58}$ Akan tetapi, yang sebenarnya dimaksudkan Torrance adalah perlu adanya pembedaan subjektivisme macam apa yang seseorang gunakan dalam memahami kebangkitan Yesus. Karena hal ini memang tidak dapat dengan begitu saja mengidentifikasi kebangkitan Yesus ke dalam "padanan" subjektif seperti yang terjadi ketika ada yang mereduksi peristiwa Paskah menjadi iman Paskah para murid.

Sebagaimana teologi alamiah menekankan esensi objek sebagai sumber pengetahuan, Torrance pun kemudian tidak memperkenankan pengetahuan apriori dalam diri manusia. Pengetahuan apriori ini pula yang ditolaknya dalam memahami peristiwa kebangkitan. Dengan pengetahuan apriori, setiap manusia dapat menciptakan suatu gagasan atau pemikiran tentang kebangkitan dalam pikiran mereka berdasarkan gambaran yang ia inginkan. Ini akan dapat memunculkan suatu subjektivisme dalam hal memahami peristiwa kebangkitan yang mengantar mereka pada pandangan doketisme ${ }^{59}$ maupun ebionisme ${ }^{60}$. Akibatnya, peristiwa

$58 \quad$ Molnar, Incarnation \& Resurrection, 113.

59 Menurut Gereja Katolik, doketisme adalah aliran bidaah yang memiliki ajaran bahwa kemanusiaan Kristus hanyalah "tampak"-nya saja atau seolah-olah la menjadi manusia yang lahir, hidup, menderita, dan wafat. Bidaah ini menolak realitas kodrat manusia yang menyatu dengan kodrat ilahi Yesus. Bdk. ---, "Docetism", https://www.britannica.com/topic/Docetism , diakses 9 Oktober 2020.

60 Ebionisme ini juga termasuk bidaah menurut Gereja Katolik. Para penganut aliran ini mempercayai bahwa Allah itu esa dan mempercayai bahwa Yesus adalah Mesias dan "nabi" yang sesungguhnya seperti yang disebutkan di Ulangan 18:15. Akan tetapi, mereka meyakini bahwa Yesus merupakan anak biologis dari Yosep dan Maria. Mereka meyakini Yesus sebagai Mesias karena la menaati hukum-hukum Yahudi atau hukumhukum taurat. Bdk. _-_-_-_, "Ebionite", https://www.britannica. com/topic/Ebionites, diakses 9 Oktober 2020. 
kebangkitan Yesus yang seharusnya menjadi objek dalam pemaknaan kebangkitan digantikan dengan iman dan harapan dari para murid bahkan penerusnya.

Posisi berbeda ditampilkan oleh Rahner. Dalam hal ini, ia menekankan kondisi eksistensi manusia sebagai makhluk historis dan transenden dan menekankan pengalaman transedental dari sebuah harapan yang dimiliki manusia sebagai titik tolak refleksi kebangkitannya. Sebagai makhluk historis dan transenden, manusia akan mengalami kematian sebagai totalitas eksistensinya. Kematian ini menjadi peristiwa yang membawa manusia pada kebangkitan. Dalam kasus kematian Yesus, ketaatan-Nya kepada kehendak Allah tidak hanya dapat memberi makna positif dari aspek kematian (totalitas eksistensi manusia), melainkan juga mentransformasi sisi negatif dari kematian (pengalaman keterbatasan manusia). Perubahan itu ada pada kematian sebagai hasil dari dosa menjadi sebuah hal yang berlawanan dengan dosa. Kematian Yesus menjadi cara Dia untuk menaati kehendak Allah untuk menebus dosa manusia. Oleh karenanya, kematian tidak lagi membawa pada sebuah kehancuran, melainkan hidup baru, yaitu hasil dari penebusan Yesus.

Karena kondisi yang terbatas ini, manusia dengan transendentalitasnya membuka diri pada harapan akan apa yang terjadi setelah kematian; manusia akan terbuka pada Ada Absolut. Ia dengan sadar akan mengarahkan dirinya pada Ada Absolut itu sebagai Allah Sang Masa Depan. Meskipun demikian, keterbukaan itu tidak hanya terjadi dalam diri manusia pada saat kematian saja. Keterbukaan dapat terjadi selama hidup manusia, karena keterbukaan manusia itu menjadi kondisi konstutif manusia sebagai penerima wahyu Allah atau pendengar sabda Allah. Terkait dengan persoalan eskatologis, khususnya kebangkitan badan, keterbukaan tersebut secara konkret terwujud dalam sebuah harapan transendental.

Bagi Rahner, harapan transendental merupakan sebuah cakrawala yang dapat membantu manusia untuk mengimani kebangkitan Yesus. Manusia berada dalam kebebasan dan tanggung jawabnya dalam hal ini. Selain itu, harapan transendental atas kebangkitan dipandang sebagai bagian dari sejarah komunikasi diri Allah melalui rahmat-Nya. Karena manusia memiliki supernatural existential yang mengarahkannya kepada Allah, harapan transendental ini membantu mengarahkan manusia pada Ada Masa Depan Absolut yang hanya dipahami dalam terang iman. Dalam iman Kristiani, Ada Masa Depan Absolut itu ada dalam pribadi Yesus Kristus. Di sinilah manusia semakin dapat memahami makna dari kebangkitan yang dialami oleh Yesus dan kebangkitan badan yang dialaminya kelak. Dengan pendekatan epistemologis ini, menjadi jelas posisi epistemologi Torrance dan Rahner. Torrance menekankan objek dan Rahner menekankan subjek dalam mengetahui kebenaran kebangkitan Yesus.

Dari pendekatan epistemologis ini didapatkan implikasi terhadap persoalan harapan-iman terhadap kebangkitan. Bagi Torrance, Yesus Kristuslah yang telah bangkit yang menjadi sumber harapan dan iman. Sebagai subjek dalam peristiwa kebangkitan, Yesus Kristus memainkan peranan yang cukup kuat dalam peristiwa kebangkitan. Karena yang bangkit ini merupakan Putera Allah, maka Dialah yang menjadi sumber harapan dan iman itu. Torrance tidak menerima sumber-sumber lain dalam harapan-iman Kristiani karena 
menghindari distorsi yang muncul karena adanya subjektivisme.

Distorsi maupun reduksi dapat terjadi jika pemaknaan kebangkitan Yesus tidak mengacu pada objek iman itu sendiri, yaitu pada peristiwa kebangkitan Yesus itu sendiri. Ia kemudian tidak menjadikan iman para rasul atas kebangkitan Yesus ini menjadi dasar iman dan harapan Kristiani seperti yang diungkapkan oleh Rahner. Hal ini akan memunculkan adanya subjektivitas atas pemaknaan peristiwa kebangkitan Yesus. Ini artinya, Torrance tidak ingin iman Paskah hanya direduksi dari iman Paskah dari para rasul.

Permasalahan ini dapat dijelaskan secara epistemologis demikian: jika struktur rasional subjek yang menentukan makna dari objek, maka objek tidak akan dapat menampakan struktur rasional intrinsiknya. Ini akan membuat adanya subjektivitas dalam pemaknaan objek. Subjektivitas ini dapat membuat reduksi maupun distorsi dari makna dari objek. Distorsi akan semakin meluas lagi jika semakin banyak subjeksubjek lain memahami pemaknaan objek dari penjelasan subjek pertama, yang sebenarnya juga sudah ada unsur subjektivitas dalam pemahamannya. Sebaliknya, jika tetap mengacu pada objek dan membiarkan objek menentukan makna dari dirinya sendiri atas subjek, reduksi tidak akan terjadi. Oleh karena itu, setiap orang tetap mengacu pada peristiwa kebangkitan Yesus sebagai objek iman dan harapan agar tidak terjadi distorsi dan reduksi dan bukan dari iman para rasul.

Keuntungan yang dimiliki para rasul adalah mereka menjadi saksi dan mengalami langsung peristiwa kebangkitan Yesus dalam bentuk penampakan-penampakan Yesus yang telah bangkit. Ini yang mendasarkan iman dan harapan mereka. Meskipun penampakan-penampakan Yesus yang telah bangkit itu bukanlah kebangkitan itu sendiri, para rasul benar-benar mengalami langsung penampakan-penampakan Yesus yang telah bangkit. Yesus yang menampakkan diri kepada para rasul itu merupakan Yesus yang telah bangkit, sehingga apa yang dialami para rasul itu, yaitu peristiwa penampakanpenampakan Yesus itu benar-benar nyata dan bukanlah hasil dari proyeksi ataupun imajinasi mereka. Karena mereka melihat langsung Yesus yang telah bangkit itulah, maka iman dan harapan mereka muncul dan mendapatkan pendasaran yang kuat. Ini menjadi semakin jelas, bahwa peristiwa kebangkitan Yesus tetaplah menjadi landasan iman dan harapan para rasul karena merupakan objek iman. Torrance membiarkan agar peristiwa kebangkitan Yesus yang mendikte dan menentukan iman dari para rasul. Gagasan Torrance ini mengandung arti bahwa antara iman para rasul dan objek iman terpisah dengan jelas dan ini sangat berbeda dengan apa yang disebutkan Rahner tentang iman para murid yang tak terpisahkan dari objek imannya.

Peristiwa kebangkitan Yesus memang menjadi objek pemaknaan atas kebangkitan. Tetapi pribadi Yesuslah yang tetap menjadi penentu sejauh mana peristiwa kebangkitan itu memiliki makna yang kuat. Yesus lah, Sang Putera Allah, yang telah bangkit dapat memberikan makna pada harapan Kristiani. Harapan Kristiani ini tidak dapat dipahami maupun dijelaskan melalui abstraksi tentang Yesus yang telah bangkit. Harapan dan iman hanya dapat dijelaskan oleh Yesus sendiri melalui karya-Nya dan kepribadianNya. Tanpa adanya tindakan konkret-Nya di dunia, yaitu kebangkitan dan kedatanganNya kembali, harapan dan iman tidak akan memiliki dasar yang kuat. 
Berkebalikan dengan Torrance, Rahner justru mendasarkan harapan-iman pada iman yang muncul dari para rasul yang pada waktu itu mengalami langsung penampakan Yesus dan makam Yesus yang kosong. Iman para rasul ini tidak terpisahkan dari peristiwa kebangkitan Yesus karena peristiwa kebangkitan Yesus menjadi objek iman yang meneguhkan iman para rasul itu sendiri. Iman para rasul inilah yang menjadi dasar iman Gereja tentang kebangkitan Yesus. Seperti yang telah disebutkan pada tema pendekatan epistemologis, harapan transendental sebagai cakrawala dalam memahami kebangkitan Yesus sudah ada dalam diri manusia.

Manusia memiliki supernatural existential yang menjadikannya terbuka pada pewahyuan Allah dalam harapan yang ada di dalamnya. Dengan kemampuannya itu, manusia senantiasa terbuka pada Allah. Demikian pula pada saat manusia memiliki sebuah harapan akan hal yang ada di masa depan, khususnya kehidupan setelah kematian. Masa depan dipahami sebagai sebuah peristiwa yang penting dari masa sekarang dan segala pengetahuan tentang masa depan Allah adalah pengetahuan tetang masa sekarang yang berciri eskatologis. ${ }^{61}$ Masa depan dapat dikatakan sebagai sebuah bentuk pemenuhan keselamatan yang sudah ada dalam komunikasi diri Allah dalam Kristus dan rahmat Roh Kudus. Rahner meyakini bahwa harapan akan masa depan itu dapat mengarahkan manusia pada Allah Sang Masa Depan Absolut, karena manusia dalam keterbatasannya mampu mentransendensikan dirinya menuju Ada yang Absolut. Meskipun gerak transendensi ini menuju sebuah kematian, manusia tidak akan berhenti pada kematian itu sendiri. Ia

Edward, "Resurrection of the Body", 368. akan terus mencari hal yang lebih daripada kematian, yaitu Allah sebagai Sang Masa Depan Absolut.

Atas dasar pemikirannya ini, Rahner menjadikan harapan transendental sebagai cakrawala untuk menerangi manusia dalam memahami kebangkitan Yesus di dalam imannya dan menerima kebenaran kebangkitan badan. Setiap orang dapat memiliki harapan transendental terhadap kebangkitan yang akan terjadi padanya. Dalam harapan transendental itu, manusia ingin bertahan dalam kondisi akhir dan kondisi yang sudah jelas secara definitif di hadapannya. Manusia berada dalam kebebasan dan tanggungjawabnya untuk menentukan dirinya secara pasti dan sampai akhir hidupnya di hadapan Allah. Ia bisa menerima atau menolak kebangkitan badan. Oleh karena itu, harapan atas kebangkitan merupakan konsekuensi praktis dari ciri kodrati kebebasan manusia.

Berkaitan dengan kebangkitan Yesus, harapan transendental tidak dapat dipisahkan dari pengalaman kesaksian para rasul. Acuan utamanya tetaplah pengalaman kesaksian para rasul akan peristiwa kebangkitan Yesus. Rahner pun kemudian menjadikan pengalaman para rasul akan peristiwa kebangkitan Yesus sebagai pijakan iman akan kebangkitan Yesus. Rahner tidak membedakan secara jelas antara objek iman dan iman yang dimiliki oleh para rasul dari peristiwa kebangkitan Yesus. Iman para rasul itu mendapatkan penegasannya dalam peristiwa kebangkitan Yesus itu sendiri. Ia menekankan bahwa memang tidak ada keterpisahan antara objek iman dan subjek iman; antara yang mengetahui dan yang diketahui. ${ }^{62}$ Rahner menuliskannya demikian: "Pada kasus para murid Yesus,

62 Molnar, Incarnation \& Resurrection, 60. 
iman Paskah dan pengalaman Paskah mereka (iman mereka dan yang menjadi dasar iman tersebut) telah saling larut tak terpisahkan." ${ }^{3}$ Rahner yakin bahwa dengan pengalaman para rasul inilah, memungkinkan manusia percaya pada kebangkitan Yesus. Ini menegaskan bahwa Rahner tidak keluar dari pengalaman manusia dalam sejarah, khususnya harapan, yaitu pengalaman para rasul untuk memahami dan meyakini bahwa kebangkitan Yesus memang layak untuk diimani. Bahkan Paul Molnar pun menegaskan bahwa Rahner lebih menekankan pada harapan dan iman manusia dalam sejarahnya untuk memaknai kebangkitan Yesus daripada Yesus yang telah bangkit melalui pencurahan Roh Kudus. ${ }^{64}$ Karena inilah, Rahner berkeyakinan bahwa kesaksian para rasul tentang kebangkitan Yesus menjadi landasan yang cukup kuat bagi Gereja untuk mendasarkan imannya kepada Yesus yang telah bangkit.

Dari pendekatan ontologis, Torrance berangkat dari titik tolak Yesus yang memiliki dua kodrat dalam satu pribadi. Dari sini ia memaknai kebangkitan Yesus yang tidak terpisahkan dari inkarnasinya di dunia. Yesus yang memiliki keilahian dalam diri-Nya secara utuh itu justru masuk pada kefanaan kemanusiaan-Nya dengan wafat di kayu salib untuk membawa-Nya pada kebangkitan. Melalui dua peristiwa tersebut, Torrance ingin menekankan bahwa dalam diri Yesus memang terdapat dua kodrat, yaitu kemanusiaan dan keilahian. Di satu sisi peristiwa inkarnasi menjadi peristiwa awal di mana Yesus Putera Allah yang sejak semula memiliki kodrat ilahi menjadi manusia

63 "In the case of Jesus' disciples their Easter faith and their Easter experience (their belief and the ground for that belief) are already blended into each other indissolubly." Karl Rahner, "Experiencing Easter", dalam Theological Investigations, volume 7, 164.

64 Molnar, Incarnation \& Resurrection, 137. dengan kodrat manusia sepenuhnya. Pada saat menjadi manusia, Ia lebih memilih untuk menyembunyikan keilahian-Nya yang agung dan penuh kuasa, khususnya pada saat penyaliban. Di sisi lain peristiwa kebangkitan menjadi penegasan bahwa Yesus memiliki badan yang dapat mati dan dapat dibangkitkan. Dalam kebangkitan itu, badan Yesus mengalami perubahan radikal dan transformasi dari badan sebelum kematian. Kebangkitan Yesus menjadi peristiwa yang secara nyata menghadirkan keilahian Yesus sebagai Putera Allah.

Penekanan pada relasi antara inkarnasi dan kebangkitan ini menegaskan sikap Torrance yang ingin melawan Kristologi yang berciri doketis dan ebionis. Baginya Perjanjian Baru memegang teguh antara kemanusiaan dan keilahian Yesus sejak dari semua. Ia ingin agar ini menjadi kerangka berpikir dalam memaknai kebangkitan sebagai datum pokok dari teologi. Untuk sampai pada pemahaman akan kebangkitan itu, Torrance mengatakan bahwa perlu memahami inkarnasi sebagai cara Allah mewahyukan diri-Nya dalam pribadi Yesus Kristus dan cara Allah untuk mendamaikan dunia yang telah terjerumus dalam dosa melalui keseluruhan hidup Yesus dari lahir sampai kebangkitan. Hal ini ingin menegaskan bahwa melalui inkarnasi Yesus, Sang Putera Allah telah bersamasama dengan manusia dalam eksistensi manusia dalam kebertubuhan-Nya di dalam ruangwaktu. Selama berinkarnasi itulah Ia menebus manusia dengan pengorbanananNya sampai di kayu salib dan mengalami kebangkitan. Kebangkitan-Nya merupakan kebangkitan badan Yesus karena eksistensi jasmani yang dimiliki-Nya. Melalui kebangkitan Yesus, Allah benar-benar berinkarnasi dan ingin menebus manusia agar selamat dari dosa-dosanya. Torrance 
dalam hal ini juga tidak memisahkan makna kebangkitan dalam ajaran penebusan.

Kebangkitan, oleh Torrance, dipandang sebagai suatu peristiwa yang unik dan merupakan mukjizat dari Allah semata. Allah membangkitkan Yesus sebagai bentuk persetujuan-Nya atas karya penebusan Putera-Nya dan merupakan penolakan atas keberdosaan manusia. Karena penolakan keberdosaan manusia itu, kebangkitan Yesus pun berdampak pada keselamatan manusia sampai pada eksisensi terdalam manusia dari masa lampau, sekarang, dan yang akan datang. Manusia mengalami penyembuhan dan pengangkatan pada sebuah tatanan baru sehingga eksistensinya kembali menjadi baik di hadapan Allah.

Sebagai sebuah mukjizat, kebangkitan Yesus ini dikaitkan dengan kelahiran-Nya dari Perawan Maria. Kelahiran-Nya ini dinilai sebagai sebuah mukjizat karena Ia dipandang sebagai "benih" yang tumbuh dari "tanah kering" Israel. ${ }^{65}$ "Benih" tidak mungkin tumbuh dan menghasilkan buah sendiri secara spontan tanpa intervensi Allah sendiri. Kelahiran Yesus inilah yang menegaskan bahwa dari "tanah kering" sekalipun "benih" tetap bisa tumbuh karena Allah bertindak atasnya. Tindakan Allah dalam kebangkitan Yesus kemudian menjadi bagian yang tak terpisahkan dari sejarah. Allah tidak membiarkan diri-Nya diam dalam kemahakuasaan-Nya.

Kebangkitan Yesus yang dimaknai sebagai sebuah mukjizat dari Allah ini memiliki dampak bagi para murid yang selalu bersamasama dengan Yesus selama masa pengajaran dan pewartaan-Nya. Dampak itu ada pada

\footnotetext{
65 Bandingkan dengan kisah Sarah, Hana, dan Elizabeth. Mereka merupakan sosok yang digambarkan mengalami mukjizat atas kehamilan mereka karena sampai pada usia senjanya, mereka tidak memiliki keturunan. Mukjizat tersebut hanya dapat dilakukan oleh kuasa Allah semata.
}

iman para murid. Dalam keempat Injil dikisahkan bahwa para murid kembali ke pekerjaannya yang dahulu pernah ditekuninya sebelum mengikuti Yesus. Mereka merasa bahwa sosok yang dijunjung tinggi itu sudah tidak ada lagi bersama-sama mereka dan tidak ada gunanya untuk melanjutkan ajaran-ajaran-Nya. Dalam situasi semacam ini, kebangkitan Yesus memberikan arti bagi iman para murid. Mereka mendapatkan peneguhan kembali atas apa yang sudah dikatakan Yesus sebelumnya, "Akulah kebangkitan dan hidup". Iman yang sudah hancur lebur itu sedikit demi sedikit mendapatkan peneguhan dan menjadi semakin kokoh dengan adanya peneguhan dari Roh Kudus yang bekerja dalam proses beriman para murid.

Pada posisi lain, Rahner pertamatama lebih menekankan kondisi eksistensi kemanusiaan Yesus yang mengalami kebangkitan. Kondisi Yesus yang telah bangkit itu mengalami perubahan radikal dan hanya dapat dipahami melalui harapan dan iman yang ada di dalam diri manusia. Ia tidak memiliki suatu permulaan dari periode hidup baru setelah kematian atau bahkan hidup yang diperpanjang karena akan melakukan hal-hal baru. Kebangkitan Yesus lebih diartikan sebagai hidup Yesus telah mencapai kebenaran akhir dan tidak akan pernah berubah lagi karena kematianNya dalam kebebasan dan ketaatan.

Karena Yesus telah bangkit, manusia percaya dan berharap pada kebangkitannya sendiri. Yesus yang bangkit itu dapat dipahami sebagai perubahan wujud dalam pribadi Yesus dan sejarah-Nya yang terakhir serta sungguh-sungguh nyata di hadapan dan di dalam Allah. Kebangkitan-Nya itu membawa-Nya pada hidup dalam kemuliaan 
bersama dengan Allah di surga. ${ }^{66}$ Bagi Rahner, kenyataan kondisi Yesus yang telah bangkit ini menjadi hal yang mendasar dan lebih penting daripada penglihatan-penglihatan maupun "penampakan-penampakan" Yesus yang telah bangkit.

Kondisi Yesus yang bangkit ini tidak dapat disamakan dengan "penampakanpenampakan" Yesus lainnya, seperti yang dialami oleh beberapa orang kudus. Agar manusia biasa dapat mempercayai apa yang terjadi dengan Yesus pada saat Dia telah bangkit, manusia membutuhkan iman dalam terang Roh Kudus. Iman ini secara fundamental terbuka pada setiap orang Kristiani. Di dalam dirinya sudah ada harapan transendental yang dapat mengarahkan untuk yakin dan percaya kepada kebangkitan Yesus. Dengan harapan transendental ini, manusia akan tergerak untuk mencari afirmasi untuk menyakinkan dirinya bahwa kebangkitan Yesus itu memang layak untuk diimani. Afirmasi itu ada pada kesaksian dari para rasul yang mengalami langsung kebangkitan Yesus. Dalam hal ini, kesaksian dan iman para rasul atas kebangkitan Yesus memiliki peran kunci bagi orang Kristiani. Bagi Rahner, kesaksian yang diberikan oleh para rasul ini merupakan kesaksian yang dapat dipercaya dan berkualitas.

Kebangkitan Yesus ini juga berdampak pada keselamatan manusia dan sejarahnya. Manusia akan mengalami suatu pembebasan dari dosa yang melingkupi eksistensinya. Meskipun kebangkitan merupakan pembaruan eksistensi manusia, akan tetapi eksistensi tersebut bukanlah keberlanjutan eksistensi manusia setelah kematian. Eksistensi manu-

\footnotetext{
Rahner mengutipnya dari Mat 22: 44 (Mzm 109:1), Why 2: 25 (Mzm 16:9-11), Rom 8: 34, Ef 8:34, Kol 3:1, Ibr 10: 12, 1 Pet 3:22 dll. Rahner, "Jesus' Resurrection", dalam Theological Investigations, volume 17, 19.
}

sia sudah mengalami totalitasnya pada saat ia mengalami kematian.

Ia tetap berpegang pada argumen bahwa apa yang terjadi dengan satu orang, akan berpengaruh pada orang lainnya. Ini juga terjadi pada kebangkitan Yesus. Baginya kebangkitan Yesus akan berdampak pada keselamatan manusia yang diawali dengan kebangkitannya, yaitu manusia dalam sejarahnya akan mengalami kebenaran secara nyata untuk pertama kalinya. Manusia tidak lagi akan mengalami kehancuran dan kehampaan setelah kematian, akan tetapi eksistensinya akan diterima dan dibebaskan oleh Allah. Dengan kata lain, Rahner menegaskan bahwa kebangkitan yang dialami oleh manusia itu bukanlah keberlanjutan dari eksistensi manusia. Eksistensi manusia sudah mengalami totalitasnya saat ia mengalami kematian. Meskipun kebangkitan dipahami bukan sebagai keberlanjutan hidup sesudah kematian, kematian tetap tidak dapat dipisahkan dari kebangkitan. Karena hanya dengan kematian, manusia dapat masuk pada kebangkitan. Ini sama seperti Yesus yang harus mengalami kematian terlebih dahulu agar dapat mengalami kebangkitan. Antara kematian dan kebangkitan pun tidak dapat dipisahkan karena keduanya saling menerangi satu sama lain.

\section{PLURALITAS YANG TAK TERHINDARKAN DALAM TEOLOGI KRISTIANI}

Perbandingan berdasarkan tiga tema yang ditawarkan oleh penulis ini semakin memberikan penegasan bahwa refleksi teologis Torrance dan Rahner tidak terlepas dari metode teologi yang digunakannya. Torrance menggunakan teologi alamiah yang menekankan objek dan Rahner 
menggunakan teologi transendental yang menekankan subjek. Dari metode teologi yang berbeda ini, dihasilkan perbedaan refleksi yang juga berbeda pula.

Perbandingan refleksi teologi Torrance dan Rahner ini hanya menjadi contoh konkret bahwa dalam teologi Kristiani metode teologi sangatlah plural dengan memiliki titik tolak yang bermacam-macam. Masih banyak metode-metode teologi dalam teologi Kristiani yang menjadi kerangka reflektif para teolog dalam mengkaji maupun merefleksikan permasalahan teologi dengan hasil kajian dan refleksi yang berbedabeda pula. Pluralitas teologi Kristiani ini menjadi suatu yang sebetulnya dapat saling memperkaya khazanah dan cakupan teologi. Adanya ajaran Gereja yang sudah menjadi "pegangan kebenaran" iman ini bukanlah menjadi suatu akhir dari refleksi teologis, melainkan menjadi permulaan untuk membuka refleksi teologi yang lebih luas dan komprehensif dengan titik tolak yang berbeda-beda.

Pluralitas semacam ini sebenarnya sudah terjadi di dalam sejarah Gereja. Artinya Gereja memang tidak dapat menyeragamkan seluruh pluralitas yang ada di dalam Gereja. Pertanyaan pun muncul : apakah dari hasil refleksi kebangkitan dari dua sudut metode teologi yang berbeda itu dapat dicari salah satu yang lebih benar dari yang lain ataukah keduanya tidak dapat dinilai dengan ukuran standar yang sama?

Dengan menggunakan kriteria kristologi dari Roger Haight ${ }^{67}$ yang juga dapat diterapkan dalam teologi secara umum, refleksi teologis dari kedua belah dapat dipertanggungjawabkan kebenarannya. Bahkan melalui kriteria tersebut justru perbedaan semakin jelas. Tidak ada yang lebih benar dari yang lainnya karena mereka sungguh mewarisi ajaran teologi Protestan dan Katolik yang dalam arti tentu tidak dapat disatukan dengan begitu saja. Karena itu mereka juga menyumbangkan gagasan yang berpengaruh pada masingmasing tradisi. Torrance menyumbangkan keberaniannya untuk berdialog dengan ilmu alam dalam teologi Protestan dan Rahner menyumbangkan ketajamannya berdialog dengan filsafat modern dalam teologi Katolik. Artinya pluralitas dalam teologi Kristiani memang tidak dapat terhindarkan dan akan terus ada. Teologi Torrance dan Rahner hanya dapat saling melengkapi sejauh ada kekurangan dari masing-masing pihak. Teologi Torrance dapat mengantisipasi subjektivitas yang dapat muncul dalam teologi Rahner dan teologi Rahner dapat mengantisipasi alineasi subjek karena peranan objek sangat kuat dalam teologi Torrance. Ini justru semakin memperkaya teologi Kristiani untuk merefleksikan suatu masalah iman zaman ini dari berbagai sudut pandang. Dengan adanya kekayaan tersebut, umat beriman manapun dan siapapun dapat menggunakannya. Yang paling penting adalah refleksi teologis itu dapat membantu umat beriman untuk semakin beriman dan dapat mewujudkan tindakan imannya dalam hidup sehari-hari.

pemberdayaan hidup Kristiani. Kriteria ketiga ini terkait erat dengan bagaimana teologi dapat mempengaruhi cara hidup Kristiani. Tanpa adanya pengaruh terhadap cara hidup Kristiani, teologi akan menjadi sebuah kajian refleksi iman yang tidak memiliki daya ubah dan hanya akan berada di atas langit belaka. Roger Haight, Jesus Symbol of God (Maryknoll: Orbis Books, 1999), 47-51. 


\section{PENUTUP}

Persoalan tentang kebangkitan masih menjadi topik yang relevan untuk menjadi suatu bahan diskusi teologis. Ajaran Gereja memang sudah menjelaskan dengan cukup baik. Akan tetapi, manusia masih belum berhenti memperdalam pemaknaan akan kebangkitan yang sudah dijelaskan di dalam ajaran Gereja. Hadirnya dua teolog besar dari dua tradisi teologi yang berbeda itu semakin memperkaya refleksi teologis tentang kebangkitan. Dua metode teologi yang berbeda itu mempengaruhi hasil refleksi mereka masing-masing. Melalui refleksi teologis ini, mereka tidak ingin

\section{DAFTAR RUJUKAN}

Edwards, Denis. "Resurrection of the Body and Transformation of the Universe in the Theology of Karl Rahner". Philosophy Theology, vol. 18, no. 2, (2006), 357-383.

Fiorenza, Francis Schüssler. "Method in Theology". Declan Marmion dan Mary E. Hines (eds.). The Cambridge Companion to Karl Rahner. Cambridge: Cambridge University Press, (2005), 65-82.

Haight, Roger. Jesus Symbol of God. Maryknoll: Orbis Books, 1999.

Hardiman, F. Budi. Heidegger dan Mistik Keseharian. Jakarta: Kepustakaan Popular Gramedia, 2003.

Irving, Alexander John Dolman. "T.F. Torrance's Natural Theology Understood in Its Intellectual Context: The Synthesis of Rational Structure and Material Content". Oxford: Disertasi Teologi The University of Oxford, 2017.

Kelly, Greffrey B. (ed.). Karl Rahner: Theologian of the Graced Search for Meaning. Minneapolis: Fortress Press, 1992.

Kennedy, Philip. Twentieth-century Theologians: A New Introduction to Modern Christian Thought. London: I.B. Tauris, 2010. McGrath, Alister. T.F. Torrance: An Intellectual Biography. Edinburgh: T\&T Clark, 1999. hanya berhenti pada ajaran Gereja. Ajaran Gereja hanya menjadi titik tolak untuk semakin memperdalam pemaknaan akan kebangkitan.

Perbedaan yang melekat kuat dari refleksi teologis ini menunjukkan bahwa pluralitas masih melekat dalam diri Gereja. Pluralitas di dalam teologi Kristiani ini justru dapat memberikan suatu tawaran bagi umat Kristiani untuk memilih refleksi mana yang dapat berpengaruh terhadap hidup beriman mereka. Dengan demikian, refleksi teologi kebangkitan harus sampai pada tataran etis hidup beriman umat Kristiani.

Molnar, Paul D. Incarnation \& Resurrection: Toward a Contemporary Understanding. Michigan: William B. Eerdmans Publishing Company, 2007.

Molnar, Paul D. Thomas F. Torrance: Theologian of The Trinity. Surrey: Ashgate, 2009.

O'Collins, Gerald. Jesus Risen: An Historical, Fundamental, and Systematic Examination of Christ' Resurrection. New York: Paulist Press, 1987.

O’Donnel, John. "Karl Rahner on Easter Faith". Gregorianum, volume 86, nomor 2, (2005), 357-367.

Regan, Ethna. "Not Merely the Cognitive Subject: Rahner's Theological Anthropology". Conway Pádraic dan Fáinche Ryan (eds.). Karl Rahner: Theologian for the Twentyfirst Century. Oxford: Peter Lang, (2019), 121-140.

Rahner, Karl. "Experiencing Easter", Theological Investigations. VII. David Boourke (penerjemah). London: Darton, Longman \& Todd, (1971), 159-168.

Rahner, Karl. Foundations of Christian Faith, William V. Dych (penerjemah). London: Darton Longman and Todd, 1978. 
Rahner, Karl., "Jesus' Resurrection”. Theological Investigations. XVII. Margaret Kohl (penerjemah). London: Darton, Longman \& Todd, (1966), 16-23.

Rahner, Karl.,On The Theology of Death. C. H. Henkey (penerjemah). Freiburg: Herder, 1961.

Sheehan, Thomas. "Pierre Rousselot and the Dynamism of Human Spirit". Gregorianum, volume 66, nomor 2, (1985), 241-267.

Torrance, Thomas F. "Natural Theology in the Thought of Karl Barth", dalam Transformation \& Convergence in the Frame of Knowledge: Explorations in the Interrelation of Scientific and Theological Enterprise. Grand Rapids: Eerdmas, (1984), 285-302.
Torrance, Thomas F., The Doctrine of Jesus Christ: Auburn Lectures, 1938-1939. Eugene: Wipf and Stock, 2002.

Torrance, Thomas F., Calvin's Doctrine of Man. London: Lutterworth Press, 1949.

Torrance, Thomas F., "The Word of God and the Nature of Man". Theology in Reconstruction. Michigan: William B. Eerdmans Publishing Company, (1965), 99-116.

Torrance, Thomas F., Reality and Scientific Theology. Edinburgh: Scottish Academic Press, 1985.

Torrance, Thomas F., Space, Time, and Resurrection. Michigan: William B. Eerdmans Publishing Company, 1976. 
